Review Article

\title{
Isotopic Tracing of Perchlorate Sources in the Environment
}

\author{
Mengnan Zhang $\mathbb{D}^{1},{ }^{1}$ Xiaoqian $\mathrm{Li}^{2}{ }^{2}$ Xuxue Cheng, ${ }^{1}$ Xinfeng Wang, ${ }^{1}$ Mian Song, \\ Xiaoyan Wang, ${ }^{1}$ and Xuemei $\mathrm{Ma}^{1}$ \\ ${ }^{1}$ Center for Hydrogeology and Environmental Geology, CGS, Baoding 071051, China \\ ${ }^{2}$ China University of Geosciences, Wuhan 430074, China
}

Correspondence should be addressed to Mengnan Zhang; saxilan@163.com

Received 11 March 2021; Accepted 16 September 2021; Published 18 October 2021

Academic Editor: Tingyue Gu

Copyright () 2021 Mengnan Zhang et al. This is an open access article distributed under the Creative Commons Attribution License, which permits unrestricted use, distribution, and reproduction in any medium, provided the original work is properly cited.

Perchlorate $\left(\mathrm{ClO}_{4}{ }^{-}\right)$is an emerging persistent pollutant that is ubiquitous in the environment at trace concentrations. Perchlorate ingestion poses a risk to human health because it interferes with thyroidal hormone production. The identification of perchlorate sources in groundwater is a primary concern. Chlorine and multi-oxygen isotopic tracing of perchlorate $\left(\delta^{37} \mathrm{Cl},{ }^{36} \mathrm{Cl} / \mathrm{Cl}, \delta^{18} \mathrm{O}\right.$, and $\left.\Delta^{17} \mathrm{O}\right)$ can provide a unique tool for identifying the origin and transport of perchlorate in groundwater. Along with the kinetic fractionation of chlorine and oxygen isotopes, the $\Delta^{17} \mathrm{O}$ value, ${ }^{36} \mathrm{Cl} / \mathrm{Cl}$ ratio, and $\varepsilon^{18} \mathrm{O} / \varepsilon^{37} \mathrm{Cl}$ (the fractionation coefficient of oxygen and chlorine isotopes) are constant, potentially indicating the biodegradation of perchlorate, without disguising its source information. Therefore, comprehensive characterization of stable chlorine and poly-oxygen isotopes is expected to provide direct evidence for identifying the source of perchlorate in groundwater. However, further studies are needed to increase the amount of isotopic data of different perchlorate sources, to make the end-member model available to broader regions. It is critically important to understand the range of values and differences of isotopes among natural perchlorate sources and the perchlorate formation mechanisms.

\section{Introduction}

Groundwater is an important water resource, which is of strategic significance to the sustainable development of a country and its people. It has become a hot issue to use water resources rationally, to ensure continued quality and availability, to meet economic and social developmental needs [1]. In some areas, groundwater is an important (or the only) source of drinking water, and water safety issues directly affect residents' health and quality of life [2]. With the rapid development in recent decades of China's economy, groundwater hydrochemistry is affected by natural factors, such as geology, geography, and climate change, and increasingly by anthropogenic inputs [3], making the situation of water shortage severe in China. Groundwater pollution is hard to be found and difficult to reverse; thus, the effective prevention and control of groundwater pollution should first be based on "prevention." That is, identifying the source of the pollutants in groundwater and determining their migration and transformation paths in groundwater are the primary concerns that should be considered to solve groundwater pollution.

Perchlorate $\left(\mathrm{ClO}_{4}^{-}\right)$is typically a persistent environmental pollutant, attracting extensive attention for research on its environmental pollution status, ecotoxicological effect, pollution control, and remediation [4-7]. Trace amounts of $\mathrm{ClO}_{4}{ }^{-}$can interfere with the normal function of the thyroid, leading to a series of developmental and metabolic diseases in the human body, especially in women of childbearing age and infants [8]. Currently, $\mathrm{ClO}_{4}{ }^{-}$widely exists in different environmental media, such as rivers, lakes, groundwater, soil, and sediment [9-11], and is widely found in food, making its way into humans at a fast rate [12-14]; it can be detected in body fluids (such as breast milk, saliva, blood, and urine) $[15,16]$, constituting a serious threat to human health. In 2008, the US Environmental Protection Agency (EPA) listed $\mathrm{ClO}_{4}{ }^{-}$as a level 1 monitoring indicator and recommended a safe reference dose of $0.7 \mu \mathrm{g} / \mathrm{kg} /$ day 
exposure to humans, which is likely to be without an appreciable risk of adverse effects. The US EPA in February 2011 officially listed $\mathrm{ClO}_{4}{ }^{-}$for regulation under the Safe Drinking Water Act; hence, perchlorate has become an important research topic.

Perchlorate originates from both natural and human sources. Natural perchlorate has been attributed to the earlier use of Chilean nitrate as fertilizer and atmospheric origin. Because perchlorate is a strong and stable oxidant and a strong acid, it is widely used in aerospace, military, and industrial fields, such as in rocket solid fuel, fireworks manufacturing, ammunition equipment, electroplating, desiccants, and oxidants (Table 1). The sources of perchlorate in groundwater vary; the pollution paths are complex and varied and are often affected by the widespread effects of physics, chemistry, and biology. Isotope technology is used to explore the source of material, related migration, and transformation laws at the "atomic" scale, having many unique advantages compared with the content measurement approach at the "molecular" scale. The comprehensive characteristics of the contents of stable chlorine and oxygen isotopes along with the radioactive isotope ${ }^{36} \mathrm{Cl}$ of perchlorate provide an important analytical tool for tracing the source of perchlorate and its migration and transformation in the environment.

China is a large traditional country of fireworks manufacturing and consumption. As the direct products of chemical plants (oxidants and additives of the perchlorate) are widely distributed throughout the country, the potential of perchlorate environmental pollution problems cannot be ignored. A recent investigation shows that $86 \%$ of 300 water samples from 13 provinces and cities in China had $\mathrm{ClO}_{4}{ }^{-}$ detected in them [17]. The concentration of $\mathrm{ClO}_{4}{ }^{-}$detected in the blood of adults in Nanchang is more than 10 times higher than that reported in the United States [12]. However, studies on the pollution of $\mathrm{ClO}_{4}{ }^{-}$in China have just begun, and the source analysis of $\mathrm{ClO}_{4}{ }^{-}$in groundwater has not been reported. Given the present situation of environmental pollution of perchlorate, this paper summarizes and discusses perchlorate isotope testing technology and its application in tracing the source of $\mathrm{ClO}_{4}{ }^{-}$in groundwater, providing a reference for effective prevention and control of $\mathrm{ClO}_{4}{ }^{-}$pollution in groundwater in China.

\section{Environmental Pollution Status of Perchlorate}

The United States was the first country to find perchlorate pollution, and existing research has mainly focused on its water pollution; thus far, $\mathrm{ClO}_{4}^{-}$has been detected in 44 states [18]. The EPA recommended that the concentration of perchlorate in drinking water be less than $15 \mu \mathrm{g} / \mathrm{L}$ [19]. The Safe Drinking Water Act (SDWA) allows States to establish drinking water standards that are more stringent than EPA's national standards. California's latest concentration standard for perchlorate in drinking water is $6 \mu \mathrm{g} / \mathrm{L}$ [18], and Massachusetts's standard is $2 \mu \mathrm{g} / \mathrm{L}$ [19]. In 2008, the US EPA recommended a safe intake of $0.7 \mu \mathrm{g} / \mathrm{kg} /$ day for the human body. $\mathrm{ClO}_{4}{ }^{-}$was detected in high amounts in the southwest of the United States, including California, Arizona, the highlands of Texas, the East Coast between New Jersey and Long Island, and Massachusetts. In 2008, the US EPA published the test results of 3,865 public water supply samples collected from 2001 to 2005, and the average content value of $\mathrm{ClO}_{4}{ }^{-}$was $4-420 \mu \mathrm{g} / \mathrm{L}$ [20]. Recently, apart from the United States, other countries have begun to investigate the concentration of $\mathrm{ClO}_{4}{ }^{-}$in water. The concentration of $\mathrm{ClO}_{4}{ }^{-}$ was $340-2,300 \mu \mathrm{g} / \mathrm{L}$ in the upstream and tributary (Usui River) of the Tone River in Japan. Moreover, different concentrations of $\mathrm{ClO}_{4}{ }^{-}$were detected in tap water from the Tone River, and a part of the water sample concentration exceeded $10 \mu \mathrm{g} / \mathrm{L}$ [21]. The concentration of $\mathrm{ClO}_{4}{ }^{-}$in the Nakdong River in South Korea is as high as $60 \mu \mathrm{g} / \mathrm{L}$, and the concentration in drinking water is as high as $35 \mu \mathrm{g} / \mathrm{L}$ [10]. The average concentration of groundwater samples from six states of India is $1.0 \mu \mathrm{g} / \mathrm{L}$, wherein samples greater than $1.0 \mu \mathrm{g} / \mathrm{L}$ were obtained from central industrial cities [22]. North Korea tested 520 tap water samples from more than 100 areas. The concentration of $\mathrm{ClO}_{4}{ }^{-}$was $<1.0-6.1 \mu \mathrm{g} / \mathrm{L}$, and $80 \%$ of the samples exceeded the concentration limit in drinking water [23]. The relevance ratio of $\mathrm{ClO}_{4}{ }^{-}$in $\mathrm{German}$ groundwater samples is $100 \%$, and the concentration is $0.79-2.38 \mu \mathrm{g} / \mathrm{L}$ [24] (Table 2).

In the past 10 years, China has also investigated perchlorate environmental pollution. The results show that the environmental pollution problem of perchlorate has been widespread in China, and research on the prevention and control of $\mathrm{ClO}_{4}^{-}$pollution in groundwater is imminent. Liu et al. reported the $\mathrm{ClO}_{4}{ }^{-}$concentration in factory water and source water of three water plants in Beijing. The results showed that $67 \%$ of the samples, with detectable $\mathrm{ClO}_{4}{ }^{-}$, were obtained from water plants that used groundwater as their water source. The concentration of $\mathrm{ClO}_{4}{ }^{-}$in the source water reached $30.7 \mu \mathrm{g} / \mathrm{L}$ [25-27]. In a recent water survey, covering 13 provinces or autonomous regions in China (including tap water, groundwater, surface water, and bottled water), the detection rate of $\mathrm{ClO}_{4}^{-}$is up to $86 \%$, with a concentration of $0.02-54.4 \mu \mathrm{g} / \mathrm{L}$, where the average concentration of groundwater was the highest, $3.04 \mu \mathrm{g} / \mathrm{L}$ [17]. Severe $\mathrm{ClO}_{4}{ }^{-}$pollution exists in Liuyang City, Hunan Province; their fireworks production accounts for more than $60 \%$ of that of the world. High concentrations of $\mathrm{ClO}_{4}{ }^{-}$are detected in the river water, bottom mud, soil, and groundwater [11, 17], among which $\mathrm{ClO}_{4}{ }^{-}$is detected in groundwater, whose concentration is as high as $22.14 \mu \mathrm{g} / \mathrm{L}$. $\mathrm{ClO}_{4}{ }^{-}$was also detected in rice and milk samples from 26 cities in China, with concentrations ranging from 0.16 to $4.88 \mu \mathrm{g} / \mathrm{kg}$ and 0.30 to $9.1 \mu \mathrm{g} / \mathrm{L}$, respectively [27]. Furthermore, the results of 131 blood samples from donors in Nanchang showed that the concentration of $\mathrm{ClO}_{4}{ }^{-}$in human blood of different age groups $(0.4-90$ year) was as high as $10.5 \mu \mathrm{g} / \mathrm{L}$, with an average value of $2.68 \mu \mathrm{g} / \mathrm{L}$ [16].

\section{Perchlorate Chlorine and Oxygen Isotope Testing Technology}

3.1. Isotope Characterization. Chlorine $(\mathrm{Cl})$ and oxygen $(\mathrm{O})$ in perchlorate $\left(\mathrm{ClO}_{4}{ }^{-}\right)$have multiple isotopes in nature. There are mainly two stable isotopes of $\mathrm{Cl}$ on the earth's 
TABLE 1: Applications of perchlorate.

\begin{tabular}{lc}
\hline Application field & Raw material \\
\hline Rocket solid fuel & $\left.\mathrm{NH}_{4} \mathrm{ClO}_{4}, \mathrm{LiClO}_{4}, \mathrm{NO}_{2} \mathrm{ClO}_{4}, \mathrm{NO}_{\bullet} \mathrm{ClO}_{4}, \mathrm{~N}_{2} \mathrm{H}_{4} \mathrm{HClO}_{4}, \mathrm{NH}_{4}\right)_{2} \mathrm{~N}_{2} \mathrm{H}_{8}\left(\mathrm{ClO}_{4}\right)_{4}$ \\
Fireworks manufacturing & $\mathrm{KClO}_{4}, \mathrm{HClO}_{4}$ \\
Electroplating & $\mathrm{HClO}_{4}$ \\
Oxidant & $\mathrm{HClO}_{4}$ \\
Desiccant & ${\mathrm{Mg}\left(\mathrm{ClO}_{4}\right)_{2}}$ \\
\hline
\end{tabular}

TABLE 2: The global pollution situation of perchlorate.

\begin{tabular}{lcc}
\hline Area & Sample concentration $(\mu \mathrm{g} / \mathrm{L})$ & Drinking water concentration $(\mu \mathrm{g} / \mathrm{L})$ \\
\hline EPA recommend & $4-420$ (public water) & 15 \\
USA & $340 \sim 2300$ (river water) & 10 \\
Japan & 60 (river water) & 35 \\
South Korea & 1.0 (groundwater) & \\
India & $<1.0 \sim 6.1 \mu \mathrm{g} / \mathrm{L}$ (tap water) & $<1.0 \sim 6.1 \mu \mathrm{g} / \mathrm{L}$ \\
North Korea & $0.79 \sim 2.38$ (groundwater) \\
German &
\end{tabular}

surface $\left({ }^{35} \mathrm{Cl}\right.$ and $\left.{ }^{37} \mathrm{Cl}\right)$ with relative abundances of $75.77 \%$ and $24.23 \%$ [28], respectively. ${ }^{36} \mathrm{Cl}$ is a trace radioisotope produced by cosmic rays in the stratosphere with a half-life of 301,000 years. There are three stable isotopes of $\mathrm{O}\left({ }^{16} \mathrm{O}\right.$, ${ }^{17} \mathrm{O}$, and ${ }^{18} \mathrm{O}$ ) with relative abundances of $99.76 \%, 0.04 \%$, and $0.20 \%$ [29], respectively. The composition of a stable isotope is usually expressed by the $\delta$ value, that is, $\delta(\%)=\left(\mathrm{R}_{\text {sample }} / \mathrm{R}_{\text {standard }}-1\right) \times 1,000$, where $\mathrm{R}_{\text {sample }}$ and $\mathrm{R}_{\text {standard }}$ represent the isotope ratios of the sample and standard, respectively. $\delta^{18} \mathrm{O}, \delta^{17} \mathrm{O}$, and $\delta^{37} \mathrm{Cl}$, respectively, can be characterized as $\delta^{18} \mathrm{O}(\%)=\left[\left({ }^{18} \mathrm{O} /{ }^{16} \mathrm{O}\right)_{\text {sample }} /\left({ }^{18} \mathrm{O} /\right.\right.$ $\left.\left.{ }^{16} \mathrm{O}\right)_{\text {VSMOW }}-1\right] \times 1,000, \quad \delta^{17} \mathrm{O}(\%)=\left[{ }^{(17} \mathrm{O} /{ }^{16} \mathrm{O}\right)_{\text {sample }} /\left({ }^{17} \mathrm{O} /\right.$ $\left.\left.{ }^{16} \mathrm{O}\right)_{\text {VSMOW }}-1\right] \times 1,000$, and $\delta^{37} \mathrm{Cl}(\% 0)=\left[\left({ }^{37} \mathrm{Cl} /{ }^{35} \mathrm{Cl}\right)_{\text {Sample }} /\right.$ $\left.\left({ }^{37} \mathrm{Cl} /{ }^{35} \mathrm{Cl}\right)_{\text {SMOC }}-1\right] \times 1,000$. Here, VSMOW and SMOC are the international standards for oxygen and chlorine isotopes, respectively. In general, for many Earth matters, there is a fixed relationship between $\delta^{17} \mathrm{O}$ and $\delta^{18} \mathrm{O} \quad\left(\delta^{17} \mathrm{O} \approx 0.52\right.$ $\left.\delta^{18} \mathrm{O}\right)$, following the mass-dependent fractionation, and $\delta^{17} \mathrm{O}$ is not normally reported. Recently, studies have found that atmospheric aerosols, such as sulfate, nitrate, and perchlorate, or surface environmental sediments have ${ }^{17} \mathrm{O}$ anomalies [25-27]. $\Delta^{17} \mathrm{O}$ is typically used to characterize ${ }^{17} \mathrm{O}$ anomalies, that is, $\Delta^{17} \mathrm{O}(\%)=\delta^{17} \mathrm{O}-0.52 \delta^{18} \mathrm{O}$ or $\Delta^{17} \mathrm{O}$ $(\%)=\left[\left(1+\delta^{17} \mathrm{O}\right) /\left(1+\delta^{18} \mathrm{O}\right) 0.525-1\right] \times 1,000$. The ${ }^{36} \mathrm{Cl}$ content is usually expressed as ${ }^{36} \mathrm{Cl} / \mathrm{Cl}$, which is the ratio of the atoms.

\subsection{Testing Technology of Perchlorate Chlorine and Oxygen} Isotopes. Research on the sources of perchlorate, geochemical behavior, and isotope kinetic fractionation effect in environmental media is still in its initial stages. The highprecision test method of stable isotope ratio provides the necessary technical support for the mechanism and application of perchlorate environmental pollution. The highprecision stable isotope data of perchlorate $\left(\delta^{18} \mathrm{O}, \Delta^{17} \mathrm{O}\right.$, and $\delta^{37} \mathrm{Cl}$ ) are usually measured using a gas stable isotope ratio mass spectrometer, and the analysis gases are $\mathrm{CO}, \mathrm{O}_{2}$, and $\mathrm{CH}_{3} \mathrm{Cl}$ [30-32]. Ader et al. and Sturchio et al. first established a test method for the $\delta^{37} \mathrm{Cl}$ value of perchlorate $[14,30-32]$. Bao and $\mathrm{Gu}$ reported a test method for the simultaneous determination of $\delta^{18} \mathrm{O}$ and $\delta^{17} \mathrm{O}$ and the preparation of $\mathrm{O}_{2}$ via high-temperature pyrolysis of perchlorate [33]. Furthermore, Böhlke et al. successively reported the preparation of $\mathrm{CO}$ via high-temperature carbon reduction of perchlorate, an online measurement $\delta^{18} \mathrm{O}$ value test method [31]. Sturchio et al. established a test method for the simultaneous analysis of $\delta^{37} \mathrm{Cl}, \delta 18 \mathrm{O}$, and $\delta^{17} \mathrm{O}$ based on the above method [30], and this method has been further adapted and developed [29, 34-36]. These methods require the analysis sample to be high-purity perchlorates, such as $\mathrm{KClO}_{4}, \mathrm{RbClO}_{4}$, or $\mathrm{CsClO}_{4}$. The ${ }^{36} \mathrm{Cl}$ content is usually determined using an accelerator mass spectrometer (AMS). This article summarizes the current mature testing techniques for perchlorate chlorine and oxygen isotopes.

3.2.1. Oxygen Isotopes. The oxygen isotope composition of perchlorate can usually be determined using two isotope ratio mass spectrometry (IRMS), namely the CO-TC/EAIRMS high-temperature carbon reduction online continuous flow method, which determines the $\delta^{18} \mathrm{O}$ value and $\mathrm{O}_{2^{-}}$ DI-IRMS pyrolysis; this off-line two-stage method measures the $\delta^{18} \mathrm{O}$ and $\delta^{17} \mathrm{O}$ values simultaneously [31, 32, 34, 35].

The principle of the CO-TC/EA-IRMS high-temperature carbon reduction online continuous flow method can be summarized as follows. Perchlorate (such as $\mathrm{CsClO}_{4}$ ) and glassy carbon in a reduction reaction in a high-temperature cracking furnace at $1,325-1,400^{\circ} \mathrm{C}$ generate $\mathrm{CO}$. After purging pure $\mathrm{He}$ carrier gas, $\mathrm{CO}$ goes through a gas chromatographic column equipped with a $5 \AA$ molecular sieve for purification. Then, it enters the IRMS in a continuous flow mode and is received by a Faraday cup with $\mathrm{m} / \mathrm{z}$ of 28 and 30 to determine the $\delta^{18} \mathrm{O}$ value. For high-purity $\mathrm{ClO}_{4}{ }^{-}$reagents and samples, the yield of $\mathrm{O}(\mathrm{CO})$ was usually $100 \pm 2 \%$, and the test accuracy of $\delta^{18} \mathrm{O}$ was $\pm 0.3 \%$ o $[31,32,35,37]$. This method can be used to rapidly and efficiently perform an online test of the perchlorate $\delta^{18} \mathrm{O}$ value, which is especially suitable for batch tests. 
For some special samples, it is necessary to measure the $\delta^{18} \mathrm{O}$ and $\delta^{17} \mathrm{O}$ values of perchlorate simultaneously; therefore, $\mathrm{O}_{2}$ must be used as the mass spectrometry gas. Perchlorate is vacuum cracked into $\mathrm{O}_{2}$ at $600-650^{\circ} \mathrm{C}$ using the two-stage method outside the pyrolysis line of $\mathrm{O}_{2}$-DI-IRMS; the reaction formula is $\mathrm{CsClO}_{4} \longrightarrow \mathrm{CsCl}+2 \mathrm{O}_{2}$. This cracking reaction can be carried out in a sealed quartz tube or Pyrex heat-resistant glass tube. Then, the produced $\mathrm{O}_{2}$ enters the IRMS in a two-way mode after purification and is received by the Faraday cups with $\mathrm{m} / \mathrm{z}$ of 32,33 , and 34 to simultaneously determine the $\delta^{18} \mathrm{O}$ and $\delta^{17} \mathrm{O}$ values [31, 32, 37]. For highpurity $\mathrm{ClO}_{4}{ }^{-}$reagents and samples, the yield of $\mathrm{O}\left(\mathrm{O}_{2}\right)$ is usually $100 \pm 5 \%$, and the test accuracy of $\Delta^{17} \mathrm{O}$ is $\pm 0.1 \%$.

3.2.2. Chlorine Isotopes. The perchlorate stable chlorine isotope composition $\left(\delta^{37} \mathrm{Cl}\right)$ was determined using the IRMS method, and the radioisotope content $\left({ }^{36} \mathrm{Cl} / \mathrm{Cl}\right)$ was determined via the AMS method.

To determine the $\delta^{37} \mathrm{Cl}$ value of perchlorate, first, the perchlorate was vacuum decomposed to produce chloride at $600-650^{\circ} \mathrm{C}$. The chloride was dissolved in deionized water, and $\mathrm{Cl}$ was precipitated as $\mathrm{AgCl}$ by adding $\mathrm{AgNO}_{3}$, which reacted with the excess $\mathrm{CH}_{3} \mathrm{I}$ in a sealed glass tube at $300^{\circ} \mathrm{C}$ for $2 \mathrm{~h}$ to produce $\mathrm{CH}_{3} \mathrm{Cl}$. The $\mathrm{CH}_{3} \mathrm{Cl}$ purified cryogenically by gas chromatography enters IRMS with continuous flow or dual-inlet mode and is measured at $\mathrm{m} / \mathrm{z}$ of 50 and 52 . The accuracy of the $\delta^{37} \mathrm{Cl}$ analysis was $\pm 0.2 \%$ o [31, 32, 35, 37].

To determine the ${ }^{36} \mathrm{Cl} / \mathrm{Cl}$ content, the same steps as above are used to convert the perchlorate to AgCl precipitate; then, the $\mathrm{AgCl}$ precipitate is dissolved in a dilute ammonia $\left(\mathrm{NH}_{4} \mathrm{OH}\right)$ solution. The $\mathrm{AgCl}$ precipitate is prepared again for the AMS measurement using $\mathrm{Cl}^{-}$, which is purified via anion chromatography or cation exchange chromatography. Typically, seawater is used as a reference substance, and its ${ }^{36} \mathrm{Cl} / \mathrm{Cl}=0.5 \times 10-15$.

\subsubsection{Collection and Preparation of $\mathrm{ClO}^{-}$Samples in} Groundwater. The IRMS measurement usually requires a sample amount of at least $0.2 \mathrm{mg} \mathrm{ClO}_{4}{ }^{-}$; thus, an effective sample preparation method is needed to achieve the isotope test of trace environmental $\mathrm{ClO}_{4}{ }^{-}$. The most successful and widely used collection and extraction method is based on a highly efficient $\mathrm{ClO}_{4}{ }^{-}$selective bifunctional anion-exchange (Figure 1) resin $[29,31,33,34,38]$. The principle is that the resin is loaded with numerous exchangeable anions. $\mathrm{ClO}_{4}{ }^{-}$ replaces the anions on the resin and is adsorbed on the resin because of the difference in the concentration of the two ions in the (Figure 1) resin when water flows through the resin [39]. This anionic resin can efficiently and selectively adsorb $\mathrm{ClO}_{4}{ }^{-}$and release $\mathrm{ClO}_{4}{ }^{-}$under the elution of a mixed solution of $1 \mathrm{M} \mathrm{FeCl}_{3}$ and $4 \mathrm{M} \mathrm{HCl}$. The resin can be reused after activation [39]. The collection and preparation of $\mathrm{ClO}_{4}{ }^{-}$ samples in groundwater is generally divided into two steps: $\mathrm{ClO}_{4}{ }^{-}$adsorption and elution. In the actual sampling process, the water sample usually passes through the filter device to remove interfering ions such as $\mathrm{Cl}^{-}, \mathrm{SO}_{4}{ }^{2-}, \mathrm{NO}_{3}{ }^{-}$, and humus, to avoid affecting the adsorption effect of $\mathrm{ClO}_{4}{ }^{-}$. The treated water then passes through the A530 E type at a flow rate of $17 \mathrm{BV} / \mathrm{min}$ resin column, comprising bifunctional anion-exchange resin (20-30 mesh). When the entire water sample passes through the resin column, most of the $\mathrm{ClO}_{4}{ }^{-}$is adsorbed on the resin and needs to be eluted to prepare the sample. First, a $4-5 \mathrm{BV}$ of $4 \mathrm{~mol} / \mathrm{L} \mathrm{HCl}$ solution or deionized water is passed through the resin column to wash off other adsorbed ions and unadsorbed $\mathrm{ClO}_{4}{ }^{-}$. Subsequently, a mixed solution of $1 \mathrm{~mol} / \mathrm{L} \mathrm{FeCl}_{3}$ and $4 \mathrm{~mol} / \mathrm{L} \mathrm{HCl}$ is prepared; the solution is passed through the resin column at a flow rate of $0.06-0.13 \mathrm{~cm} / \mathrm{min}$. $\mathrm{NaOH}$ is added to the obtained eluent and centrifuged to obtain the supernatant. $\mathrm{CsCl}$ is added to the supernatant, heated, and evaporated to obtain $\mathrm{CsClO}_{4}$ precipitation, which is prepared for mass spectrometry tests after purification [29, 40].

\section{Isotope Tracing of Chlorine and Oxygen from Perchlorate}

4.1. Isotopic Composition Characteristics of Perchlorate from Different Sources. Perchlorates from different sources have characteristic isotopic composition values related to their formation mechanism; perfecting and establishing an endmember model of their sources is a necessary basis for the application of isotope technology to trace the source. The existing natural origin and synthetic perchlorate isotope data show that the comprehensive characteristics of chlorine and oxygen isotopes of perchlorate are expected to provide direct evidence for identifying the source of perchlorate in groundwater.

4.1.1. Synthetic Perchlorate. Synthetic perchlorate is usually produced by the electrolytic oxidation of $\mathrm{NaCl}$. The perchlorate production process largely depends on the content of the raw material $\mathrm{Cl}$, while the electrolyzed water provides an O source for the synthesis of perchlorate. Since 2001, American scholars have analyzed the isotopic composition of various perchlorate reagents (used in laboratories, industry, and military) and products (used in road blasting, fireworks, pesticides, bleaching agents, and propellants). According to reported data $[14,31,33,34,42]$, the synthetic perchlorate $\delta^{37} \mathrm{Cl}$ value is $-3.1 \%$ o to $+2.3 \%$; the $\delta^{18} \mathrm{O}$ value is $-24.8 \%$ o to $-12.5 \%$; the $\Delta^{17} \mathrm{O}$ value is $0.0 \pm 0.1 \%$; the ratio of ${ }^{36} \mathrm{Cl} / \mathrm{Cl}$ is $\leq 2.5 \times 10-15-40 \times 10-15$; and the average value of $\delta^{37} \mathrm{Cl}$ of synthetic perchlorate is about $+0.6 \%$, which is similar to the $\delta^{37} \mathrm{Cl}$ value of raw material, $\mathrm{NaCl}$ (0.0 $\pm 10-15) 0.9 \%$ ) [43]. A similar value indicates that there is almost no fractionation of chlorine isotopes during the process of synthesizing perchlorate by electrolytic oxidation. The $\delta^{18} \mathrm{O}$ value has a larger range of variation, which may be related to the isotope composition of the water source used in the perchlorate production process and oxygen isotope fractionation [32]. Preliminary studies have shown that $\mathrm{ClO}_{4}{ }^{-}$produced by the disproportionation reaction of commercial bleach $(\mathrm{NaOCl})$ solution has an abnormally high $\delta^{37} \mathrm{Cl}$ value $(+14.0 \%$ ) [42]. Therefore, the isotopic composition of perchlorate is not only related to the isotopic composition of its raw materials but may also be affected by its production process. 

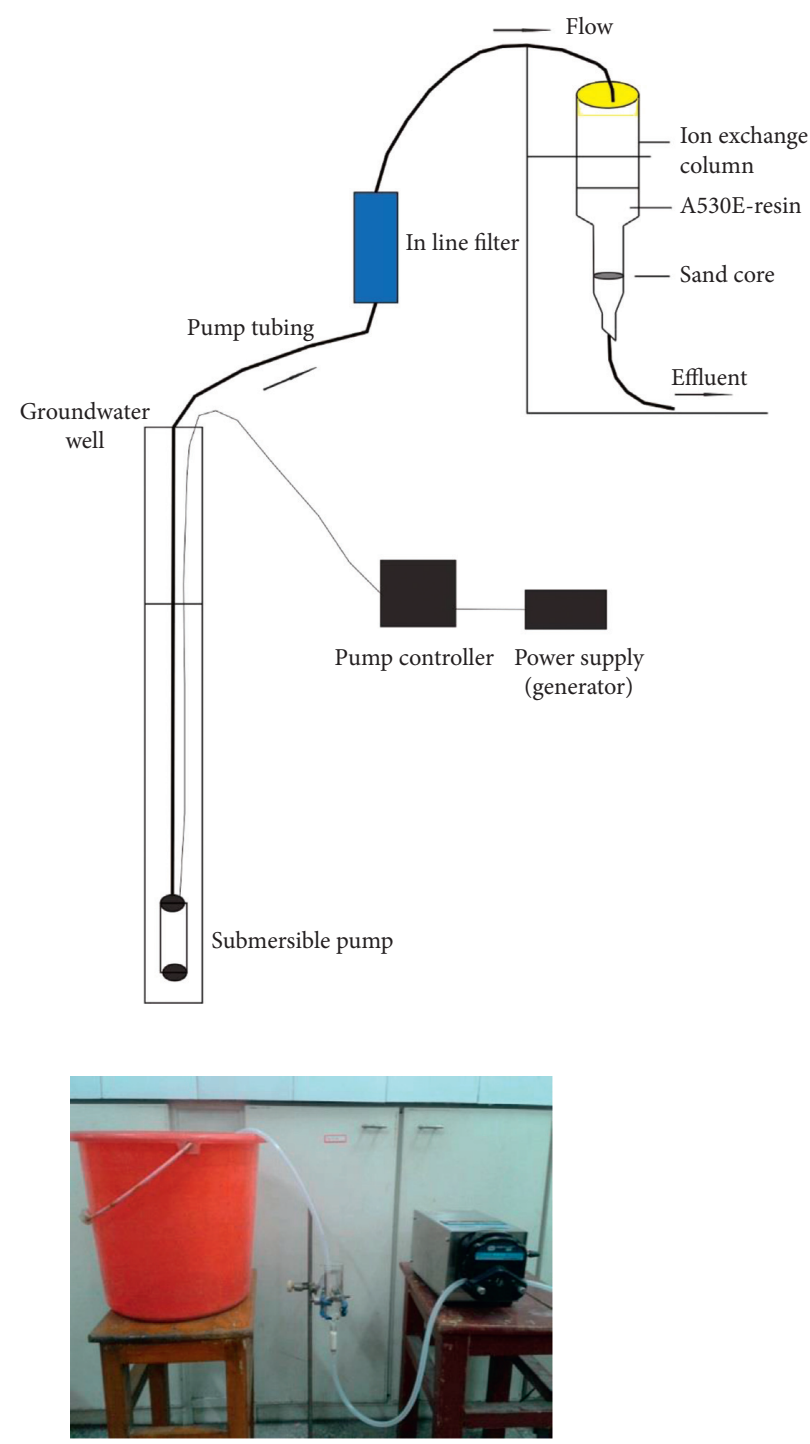

Figure 1: Sample collection device [41] (the left picture is the device used in the lab by authors).

4.1.2. Perchlorate of Natural Origin. It has been reported that perchlorate of natural origin is mainly distributed in the Atacama Desert in northern Chile and in the arid region of the southwestern United States. However, there are regions (such as the southern high plains and eastern New Mexico) where there is no clear historical or current evidence of the presence of rocket fuel or Chilean fertilizer sources. In these regions, perchlorate has been attributed to meteoric $\mathrm{ClO}_{4}{ }^{-}$ that accumulated in the unsaturated zone, with subsequent flushing to groundwater by the advent of the irrigation $[44,45]$. They have distinctly different isotopic compositions from synthetic perchlorates, and the isotopic compositions in the two regions have their own characteristics.

The Chilean saltpeter in the Atacama Desert is the most typical naturally occurring mineral that is rich in $\mathrm{ClO}_{4}{ }^{-}$. However, owing to the differences in sampling locations and detection methods, the mass content of $\mathrm{ClO}_{4}{ }^{-}$reported in the literature is not the same, ranging from $0.03 \%$ to $3.6 \%$ [46-48]. Chilean saltpeter is an important raw material for fertilizers, and the total amount of Chilean saltpeter (imported by the United States and widely used in agriculture decades ago) has reached millions of tons [49]. It was an important potential source of $\mathrm{ClO}_{4}{ }^{-}$in groundwater (but now with the development of processing the percentage of perchlorate in Chilean fertilizers has been reduced). Bao and $\mathrm{Gu}$ first reported the oxygen isotopic composition of $\mathrm{ClO}_{4}{ }^{-}$ in Chilean saltpeter; that is, the $\delta^{18} \mathrm{O}$ value ranged from $-24.8 \%$ to $-4.5 \%$, and the $\Delta^{17} \mathrm{O}$ value ranged from $+4.2 \%$ to $+9.6 \%$ [47]. Furthermore, some scholars have successively expanded their oxygen isotope data [31, 32, 34], where the $\delta^{18} \mathrm{O}$ value ranged from $-9.3 \%$ to $-2.2 \%$, and the $\Delta^{17} \mathrm{O}$ value ranged $+7.9 \%$ o to $+18.4 \%$. The large positive ${ }^{17} \mathrm{O}$ anomaly of $\mathrm{ClO}_{4}{ }^{-}$in Chilean saltpeter may be the result of the photochemical interaction of atmospheric $\mathrm{Cl}$ and $\mathrm{O}_{3}$, indicating that $\mathrm{ClO}_{4}{ }^{-}$in natural minerals originated from the atmosphere, and was deposited and preserved in an arid climate with strong evaporation. The $\delta^{37} \mathrm{Cl}$ value of $\mathrm{ClO}_{4}{ }^{-}$in Chilean saltpeter ranges from $-14.5 \%$ o to $-11.8 \%$ o $[31,32,34]$, and the ratio of ${ }^{36} \mathrm{Cl} / \mathrm{Cl}$ is $22 \times 10-15-590 \times 10-15$ [42]. 
Natural perchlorate is widely distributed throughout the arid and semiarid regions of the world, such as the southwestern United States, the southern high plains of United States, and Chile $[48,50]$. Perchlorate is widely distributed on the earth, but the deep research has regional limitations. The scientists have collected samples for stable isotope analysis in several regions. The $\delta^{18} \mathrm{O}, \Delta^{17} \mathrm{O}$, and $\delta^{37} \mathrm{Cl}$ values of $\mathrm{ClO}_{4}{ }^{-}$in groundwater in the southern plateau area range from $+0.55 \%$ to $+4.8 \%$, $+0.3 \%$ o to $+1.3 \%$, and $+3.4 \%$ o to $+5.1 \%$, respectively; meanwhile, the DV area is an unsaturated zone. The $\delta^{18} \mathrm{O}, \Delta^{17} \mathrm{O}$, and $\delta^{37} \mathrm{Cl}$ values of $\mathrm{ClO}_{4}{ }^{-}$in the sodium nitrate deposit in ore deposits ranges from $+2.9 \%$ o to $+26.1 \%$, $+8.6 \%$ o to $+18.4 \%$, and $-3.1 \%$ o to $-0.8 \%$ o, respectively. The ${ }^{36} \mathrm{Cl} / \mathrm{Cl}$ ratio of $\mathrm{ClO}_{4}{ }^{-}$in arid southwestern United States is $3,130 \times 10-15-28,800 \times 10-15$ [42].

4.1.3. Comparison of Isotopic Composition of Perchlorate from Different Sources. Based on the known isotope data of perchlorate, the relation chart of $\delta^{37} \mathrm{Cl}$ versus $\delta^{18} \mathrm{O}, \Delta^{17} \mathrm{O}$ versus $\delta^{18} \mathrm{O}$, and ${ }^{36} \mathrm{Cl} / \mathrm{Cl}$ versus $\delta^{37} \mathrm{Cl}$ were plotted (Figure 2). Figure 1 shows that the $\delta^{37} \mathrm{Cl}$ value $(-3 \%$ to $+2 \%$ o of synthetic $\mathrm{ClO}_{4}^{-}$partially overlaps the $\delta^{37} \mathrm{Cl}$ value $(-3 \%$ o to $+6 \%$ ) of naturally originated $\mathrm{ClO}_{4}{ }^{-}$in the arid area of the southwestern United States. $\mathrm{ClO}_{4}^{-}$in saltpeter has a significantly negative $\delta^{37} \mathrm{Cl}$ value $(-15 \%$ o to $-19 \%$ o). The reason why natural $\mathrm{ClO}_{4}^{-}$has an extensive range of $\delta^{37} \mathrm{Cl}$ values is not apparent; it may be related to the regional origin of atmospheric chlorine or the formation mechanism of $\mathrm{ClO}_{4}{ }^{-}$. The synthetic $\mathrm{ClO}_{4}{ }^{-}$has a significantly different oxygen isotope composition than that of natural $\mathrm{ClO}_{4}{ }^{-}$. The $\Delta^{17} \mathrm{O}$ value of synthetic $\mathrm{ClO}_{4}^{-}$is approximately 0 , while natural $\mathrm{ClO}_{4}{ }^{-}$has a positive $\Delta^{17} \mathrm{O}$ value; hence, the $\Delta^{17} \mathrm{O}$ value is the most sensitive and accurate indicator for identifying synthetic and naturally originated $\mathrm{ClO}_{4}{ }^{-}$. However, natural $\mathrm{ClO}_{4}{ }^{-}$in different regions shows different degrees of ${ }^{17} \mathrm{O}$ anomalies, which may be due to the different formation mechanisms and pathways of atmospheric $\mathrm{ClO}_{4}{ }^{-}$and its occurrence in environment. Estrada et al. have summarized some reactions possibly leading to the formation of $\mathrm{ClO}_{4}{ }^{-}$via $\mathrm{O}_{3}$ and $\mathrm{UV}$ oxidation of $\mathrm{ClO}_{\mathrm{x}}$ species [51]. Generally, $\mathrm{ClO}_{4}{ }^{-}$formed by atmospheric $\mathrm{O}_{3}$ oxidation has a larger $\Delta^{17} \mathrm{O}$ value, while $\mathrm{ClO}_{4}{ }^{-}$formed by photochemical reactions or lightning effects has a smaller $\Delta^{17} \mathrm{O}$ value. The ${ }^{17} \mathrm{O}$ abnormal signal can be preserved for thousands or even millions of years in arid environments. ${ }^{36} \mathrm{Cl}$ is mainly produced by cosmic rays in the stratosphere; thus, atmospheric-derived $\mathrm{ClO}_{4}{ }^{-}$has a higher ${ }^{36} \mathrm{Cl} / \mathrm{Cl}$ ratio, while synthetic $\mathrm{ClO}_{4}{ }^{-}$has a lower ${ }^{36} \mathrm{Cl} / \mathrm{Cl}$ ratio.

4.2. Fractionation Characteristics of Isotopes during the Biodegradation of Perchlorate. The biodegradation of $\mathrm{ClO}_{4}{ }^{-}$is a multi-stage reaction catalyzed by reductase $[52,53]$, which can be divided into three steps: $\mathrm{ClO}_{4}{ }^{-} \longrightarrow \mathrm{ClO}_{3}{ }^{-} \longrightarrow \mathrm{ClO}_{2}{ }^{-} \longrightarrow \mathrm{Cl}^{-}+\mathrm{O}_{2}$. The biodegradation of $\mathrm{ClO}_{4}{ }^{-}$is often accompanied by the fractionation of stable chlorine and oxygen isotopes. Previous laboratory and field studies have conducted experiments for preliminary research on the degree and characteristics of fractionation. Coleman et al. [54] and Sturchio et al. [30] used Azospira suillum bacteria to conduct liquid culture medium experiments, to determine the dynamic fractionation effect of $\mathrm{Cl}$ isotopes, wherein acetate was the electron donor and $\mathrm{ClO}_{4}{ }^{-}$ was the only electron acceptor. By conducting two separate culture fluid experiments $\left(\mathrm{ClO}_{4}{ }^{-}\right.$complete degradation time is about $90 \mathrm{~min}$ ), Coleman et al. obtained $\varepsilon^{37} \mathrm{Cl}$ values of $-15.8 \pm 0.4 \%$ and $-14.8 \pm 1.3 \%$ at $37^{\circ} \mathrm{C}$. By performing the culture solution experiment, which has different degradation rates $\left(\mathrm{ClO}_{4}{ }^{-}\right.$complete degradation time is 18 days and $\left.5.5 \mathrm{~h}\right)$. Sturchio et al. obtained $\varepsilon^{37} \mathrm{Cl}$ values at $22^{\circ} \mathrm{C}$ of $-16.6 \%$ and $-12.9 \%$, respectively. Ader et al. [55] obtained a more accurate $\varepsilon^{37} \mathrm{Cl}$ value $(-14.98 \pm 0.15 \%$ o $)$ based on the statistical analysis of experimental data (reported by Coleman et al.). Additionally, Sturchio et al. [53] performed further experiments using two different strains (A. suillum JPLRND and Dechlorospirillum sp. FBR2) to degrade $\mathrm{ClO}_{4}{ }^{-}$in liquid culture at $22^{\circ} \mathrm{C}$ and $10^{\circ} \mathrm{C}$, respectively, and simultaneously determined the fractionation effect of $\mathrm{Cl}$ and $\mathrm{O}$. The values of $\varepsilon^{37} \mathrm{Cl}$ and $\varepsilon^{18} \mathrm{O}$ were $-13.2 \pm 0.5 \%$ and $-33.1 \pm 1.2 \%$, respectively, and the value of $\varepsilon^{18} \mathrm{O} / \varepsilon^{37} \mathrm{Cl}$ of the remaining proportion of $\mathrm{ClO}_{4}{ }^{-}$is always constant $(2.50 \pm 0.04)$. Sturchio et al. also used ${ }^{18} \mathrm{O}$-rich heavy oxygen water to test whether oxygen isotope exchange occurred between $\mathrm{ClO}_{4}{ }^{-}$ and $\mathrm{H}_{2} \mathrm{O}$ during the biodegradation process. The experimental results did not show the occurrence of an oxygen isotope exchange reaction [53]. This indicated that biodegradation did not change the $\Delta^{17} \mathrm{O}$ value of $\mathrm{ClO}_{4}{ }^{-}$. The push-pull field experiment of in situ aquifers conducted by Hatzinger et al. [36] showed that the $\varepsilon^{37} \mathrm{Cl}$ and $\varepsilon^{18} \mathrm{O}$ values are only $0.3-0.4$ times that of the indoor experiment, whereas the $\varepsilon^{18} \mathrm{O} / \varepsilon^{37} \mathrm{Cl}$ ratio (2.63) is consistent with the measured value of the indoor experiment. Therefore, the consistency of the $\varepsilon^{18} \mathrm{O} / \varepsilon^{37} \mathrm{Cl}$ ratio between the indoor and in situ experiments in the field provides a possibility for stable chlorine and oxygen isotopes being able to indicate the biodegradation of perchlorate without concealing its source information. In Figure 3, the set of parallel dashed lines with arrows indicates the changing trend of the $\delta^{37} \mathrm{Cl}$ and $\delta^{18} \mathrm{O}$ values of $\mathrm{ClO}_{4}{ }^{-}$during the biodegradation of $\mathrm{ClO}_{4}^{-}$. The concentration of $\mathrm{ClO}_{4}{ }^{-}$ (remaining fraction F) can be used to inversely calculate the isotope composition before biodegradation.

4.3. Application Examples of Isotope Tracer of $\mathrm{ClO}_{4}^{-}$in Groundwater. Investigating and determining the isotopic composition of different sources of $\mathrm{ClO}_{4}{ }^{-}$provide necessary data support for establishing the end-member model of the isotope characteristic value of different sources of $\mathrm{ClO}_{4}^{-}$. The isotope kinetic fractionation characteristics of $\mathrm{ClO}_{4}{ }^{-}$biodegradation provide a theoretical basis for tracing the source of $\mathrm{ClO}_{4}{ }^{-}$in environmental media. The Chino Basin in California, Long Island in New York, and San Bernardino Basin in California are three typical $\mathrm{ClO}_{4}{ }^{-}$-contaminated aquifers. The isotopic composition of $\mathrm{ClO}_{4}^{-}\left(\delta^{37} \mathrm{Cl}, \delta^{18} \mathrm{O}\right.$, and $\left.\Delta^{17} \mathrm{O}\right)$ in groundwater in the three regions was plotted on the endmember model diagram of the isotopic composition of $\mathrm{ClO}_{4}{ }^{-}$from different sources (as shown in Figure 4). The comprehensive characteristics of $\mathrm{Cl}$ and poly-oxygen 

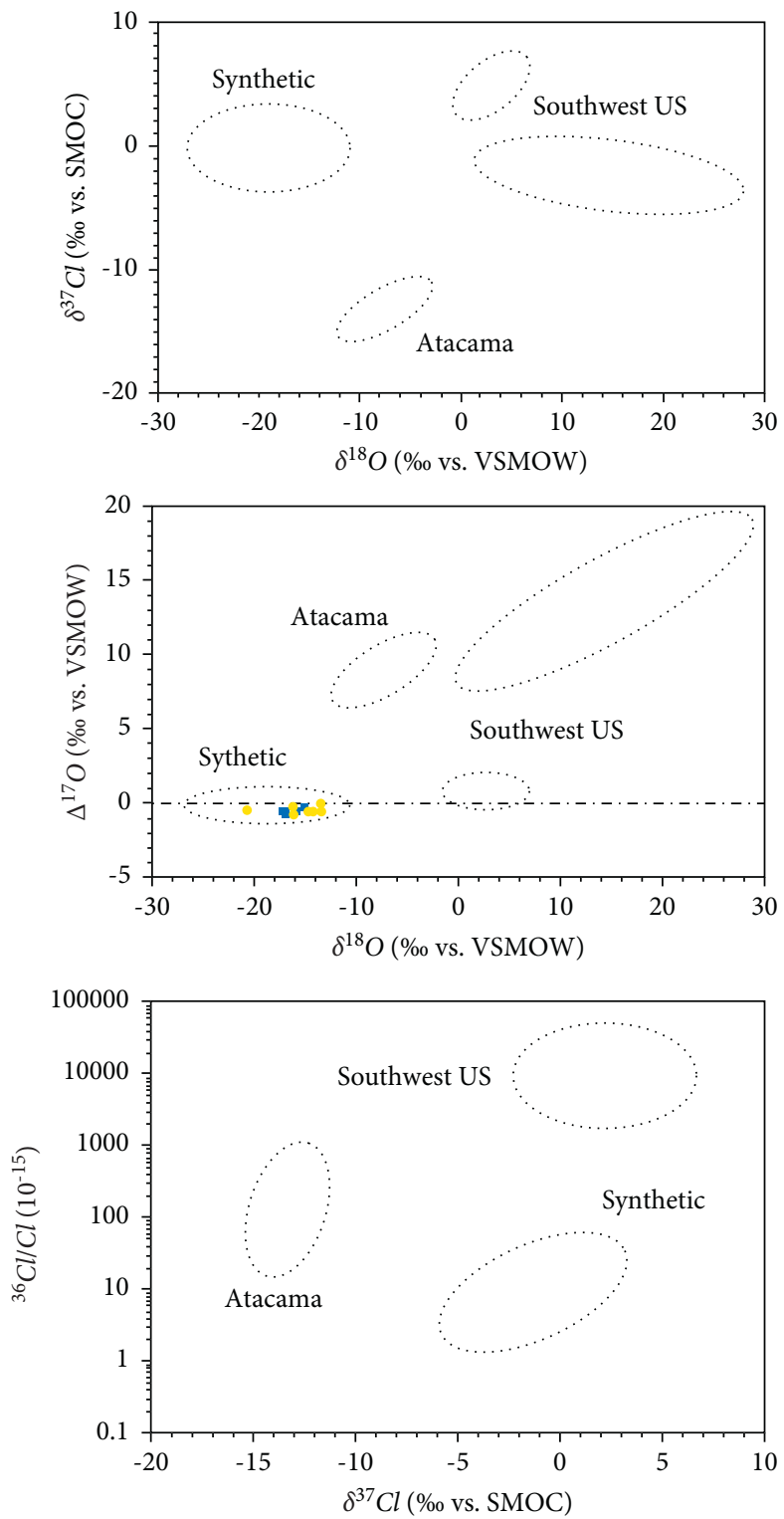

Figure 2: $\delta^{37} \mathrm{Cl}(\%)$ versus $\delta^{18} \mathrm{O}(\%)$ values (upper diagram) and $\Delta^{17} \mathrm{O}\left(\%\right.$ ) versus $\delta^{18} \mathrm{O}(\%$ ) values (middle diagram) for samples of synthetic $\mathrm{ClO}_{4}^{-}$, Atacama $\mathrm{ClO}_{4}^{-}$, and southwest $\mathrm{ClO}_{4}{ }^{-}$. Southwest $\mathrm{ClO}_{4}{ }^{-}$is subdivided into southern $\mathrm{SHP}$ and $\mathrm{DV}[31,32,34]$. ${ }^{36} \mathrm{Cl} / \mathrm{Cl}$ versus $\delta^{37} \mathrm{Cl}(\%)$ values (bottom diagram) for samples of synthetic $\mathrm{ClO}_{4}{ }^{-}$, Atacama $\mathrm{ClO}_{4}{ }^{-}$, and Southwest $\mathrm{ClO}_{4}{ }^{-}$[42]. The colored points represent the isotope value of some analytical reagents and firework samples measured by the authors (purple points: $\mathrm{KClO}_{4}$, $\mathrm{CsClO}_{4}$, $\mathrm{NaClO}_{4}, \mathrm{RbClO}_{4}$, and $\mathrm{Mg}\left(\mathrm{ClO}_{4}\right)_{2}$ and blue points: firework samples).

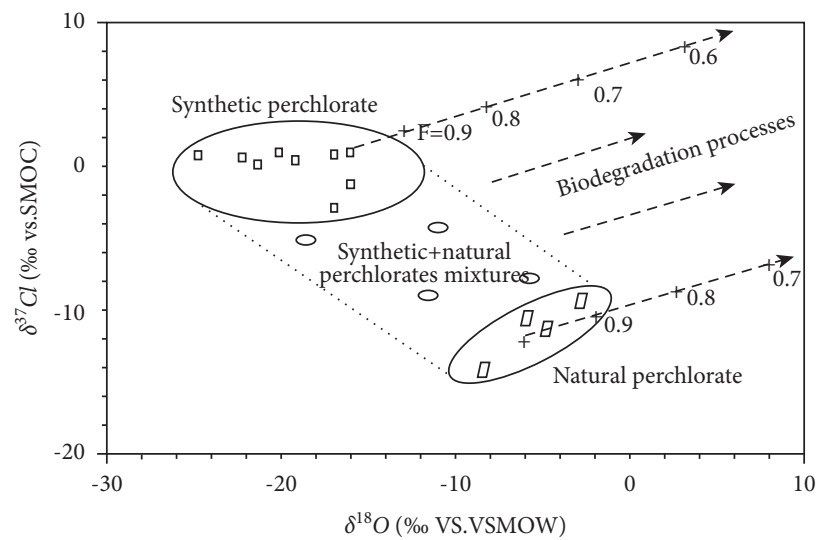

Figure 3: Schematic relation between characteristic $\delta^{37} \mathrm{Cl}$ and $\delta^{18} \mathrm{O}$ values (per mil) of synthetic and natural perchlorate samples during biodegradation processes [53]. 

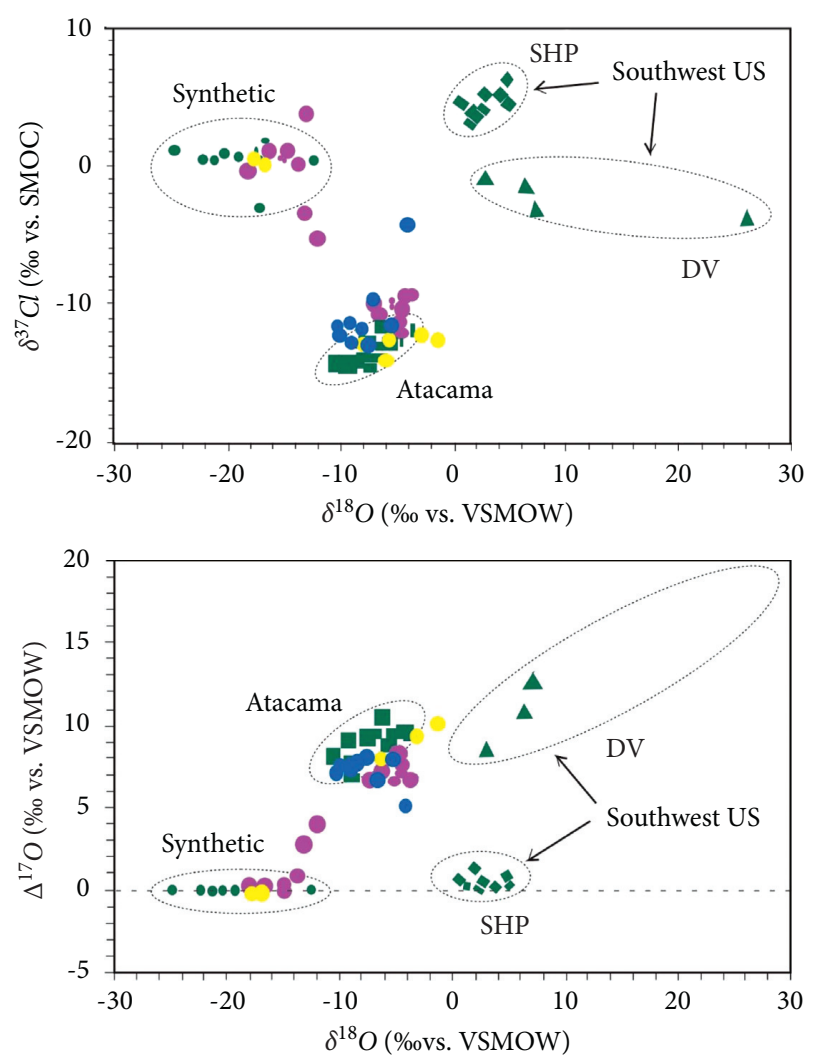

Figure 4: $\delta^{37} \mathrm{Cl}(\%)$ versus $\delta^{18} \mathrm{O}(\%)$ values and $\Delta^{17} \mathrm{O}(\%)$ versus $\delta^{18} \mathrm{O}(\%)$ values show stable isotope data for $\mathrm{ClO}_{4}{ }^{-}$in groundwater samples from the Chino Basin, California (blue symbols) [56], Long Island, New York (yellow symbols) [57], and southeastern San Bernardino Basin, California (red symbols) [58] in comparison to the principal known source types in the region, which is shown in Figure 1.

isotopes in the groundwater of the three regions indicated that the main source of $\mathrm{ClO}_{4}{ }^{-}$in the groundwater of the Chino Basin in California was Chilean saltpeter from the Atacama Desert, which is used as agricultural fertilizer [56]. The source of $\mathrm{ClO}_{4}{ }^{-}$in the groundwater of Long Island in New York was Chilean saltpeter from the Atacama Desert and synthetic $\mathrm{ClO}_{4}{ }^{-}$[57]. The source of $\mathrm{ClO}_{4}{ }^{-}$in the groundwater in the San Bernardino Basin of California is Chilean saltpeter from the Atacama Desert and synthetic $\mathrm{ClO}_{4}{ }^{-}$from the rocket test site; some areas are a mix of the two pollution plumes [58].

\section{Conclusion and Outlook}

Perchlorates from different sources have different isotopic characteristic values $\left(\delta^{18} \mathrm{O}, \Delta^{17} \mathrm{O}, \delta^{37} \mathrm{Cl}\right.$, and $\left.{ }^{36} \mathrm{Cl} / \mathrm{Cl}\right)$ and are related to their formation mechanisms. The ${ }^{17} \mathrm{O}$ abnormal signal can be preserved for thousands or even millions of years in arid environments. Even if the biodegradation of perchlorate occurs under some specific conditions, along with the kinetic fractionation of chlorine and oxygen isotopes, its $\Delta^{17} \mathrm{O}$ value or ${ }^{36} \mathrm{Cl} / \mathrm{Cl}$ ratio will not change. Moreover, $\varepsilon^{18} \mathrm{O} / \varepsilon^{37} \mathrm{Cl}$ (the fractionation coefficient of oxygen and chlorine isotopes) is constant, potentially revealing the biodegradation of perchlorate without disguising its source information. Therefore, the comprehensive characteristics of stable chlorine and poly-oxygen isotopes are expected to provide direct evidence for identifying the source of perchlorate in groundwater. However, further studies are needed to qualitatively identify and quantitatively evaluate perchlorate pollution sources.

(1) The key problem in applying multi-isotope technology to identify the source of perchlorate in groundwater is to effectively distinguish the characteristic values of the end-member isotopes of different sources of perchlorate. Current research achievements are mainly limited to the United States and Chile and have apparent geographic limitations. The effective analysis of the source of perchlorate in polluted aquifers in different regions needs to be enriched by the isotope characteristic values and end-member model.

(2) Nonmass fractionation of oxygen isotopes $\left(\Delta^{17} \mathrm{O}>0\right)$ is a unique feature of natural perchlorate, which can effectively distinguish between natural sources of perchlorate and synthetic pollution sources. The isotopic composition characteristics of natural perchlorate show apparent differences in different regions and environments. To characterize its isotopic composition characteristics on a global scale and reveal the formation mechanism, it is necessary to analyze and study more representative samples from different regions.

(3) Perchlorate pollution in groundwater is mostly caused by natural sources, and some are caused by human activities [59]. Natural and synthetic perchlorates have significantly different isotope characteristic values. Natural perchlorate isotope characteristic values have apparent geographic limitations (limited to the United States and Chile), so the more important research is to supplement the isotope signatures from other regions. At this stage, there is still considerable uncertainty in the distinction between synthetic perchlorate pollution sources. The perchlorate products produced by the same production process have similar chlorine isotope compositions; however, oxygen isotope compositions are quite different, which may be related to the water source used in the production process. Research on the isotope composition of synthetic perchlorate, its production process, and other influencing factors can provide a theoretical basis for effectively distinguishing the synthetic pollution sources of perchlorate.

\section{Data Availability}

The data used to support this study are from previous studies and experiments.

\section{Conflicts of Interest}

The authors declare that they have no conflicts of interest. 


\section{Acknowledgments}

The study involved in this paper was supported by the projects Hydrogeological Survey of Weihe River Basin (DD20190333); Hydrogeological Survey of Sanjiang Plain (DD20190339); Stable Chlorine and Multi-Oxygen Isotopic Tracing of Perchlorate in Groundwater (41202169); and New Measurement Technique for Stable Chlorine and Oxygen Isopotic Compositions of Perchlorate in Groundwater (2012M511702).

\section{References}

[1] Z. Gao, Z. Wang, S. Wang et al., "Factors that influence the chemical composition and evolution of shallow groundwater in an arid region: a case study from the middle reaches of the Heihe River, China," Environmental Earth Sciences, vol. 78, no. 14, p. 390, 2019.

[2] J. Liu, Y. Peng, C. Li, Z. Gao, and S. Chen, "Characterization of the hydrochemistry of water resources of the Weibei plain, Northern China, as well as an assessment of the risk of high groundwater nitrate levels to human health," Environmental Pollution, vol. 268, Article ID 115947, 2021.

[3] J. Liu, Y. Peng, C. Li, Z. Gao, and S. Chen, "An investigation into the hydrochemistry, quality and risk to human health of groundwater in the central region of Shandong Province, North China," Journal of Cleaner Production, vol. 282, Article ID 125416, 2021.

[4] Z. Wen, W. Zheng, H. Shen, and M. Hu, "Research progress on the hazards, water pollution status and removal technique of perchlorate," Environmental Chemistry, January, vol. 38, 2019.

[5] E. Stokstad, "Perchlorate study suggests lower risk," Science, vol. 307, no. 5707, p. 191b, 2005.

[6] E. Stokstad, "Environmental health: debate continues over safety of water spiked with rocket fuel," Science, vol. 307, no. 5709, p. 507, 2005.

[7] Y. Jia, X. Tang, and L. Jiaren, "Research advance in effect of perchlorate on human health," Environmental Health, vol. 25, 2008.

[8] Z. Liao, D. Cao, Z. Gao, and S. Zhang, "Occurrence of perchlorate in processed foods manufactured in China," Food Control, vol. 107, Article ID 106813, 2020.

[9] K. Kosaka, M. Asami, Y. Matsuoka, M. Kamoshita, and S. Kunikane, "Occurrence of perchlorate in drinking water sources of metropolitan area in Japan," Water Research, vol. 41, no. 15, pp. 3474-3482, 2007.

[10] O. Quiñones, J.-E. Oh, B. Vanderford, J. H. Kim, J. Cho, and S. A. Snyder, "Perchlorate assessment of the Nakdong and Yeongsan watersheds, Republic of Korea," Environmental Toxicology \& Chemistry, vol. 26, no. 7, pp. 1349-1354, 2007.

[11] Y. Shi, J. Gao, and L. Xin, "The investigation of perchlorate pollution level in Liuyang River water, sediment and its nearby soil," Environmental Chemistry, vol. 29, no. 3, pp. 388-391, 2010.

[12] C. A. Sanchez, B. C. Blount, L. Valentin-Blasini, S. M. Lesch, and R. I. Krieger, "Perchlorate in the feed-dairy continuum of the southwestern United States," Journal of Agricultural and Food Chemistry, vol. 56, no. 13, pp. 5443-5450, 2008.

[13] S. A. Snyder, R. C. Pleus, B. J. Vanderford, and J. C. Holady, "Perchlorate and chlorate in dietary supplements and flavor enhancing ingredients," Analytica Chimica Acta, vol. 567, no. 1, pp. 26-32, 2006.
[14] M. Ader, M. L. Coleman, S. P. Doyle, M. Stroud, and D. Wakelin, "Methods for the stable isotopic analysis of chlorine in chlorate and perchlorate compounds," Analytical Chemistry, vol. 73, no. 20, pp. 4946-4950, 2001.

[15] T. Zhang, Q. Wu, H. W. Sun, J. Rao, and K. Kannan, "Perchlorate and iodide in whole blood samples from infants, children, and adults in Nanchang, China," Environmental Science \& Technology, vol. 44, no. 18, pp. 6947-6953, 2010.

[16] L. Valentín-Blasini, J. P. Mauldin, D. Maple, and B. C. Blount, "Analysis of perchlorate in human urine using ion chromatography and electrospray tandem mass spectrometry," Analytical Chemistry, vol. 77, no. 8, pp. 2475-2481, 2005.

[17] Q. Wu, T. Zhang, H. Sun, and K. Kannan, "Perchlorate in tap water, groundwater, surface waters, and bottled water from China and its association with other inorganic anions and with disinfection byproducts," Archives of Environmental Contamination and Toxicology, vol. 58, no. 3, pp. 543-550, 2010.

[18] S. Jiang, Y. Li, and H. Ma, "Source, pollution status and analytical methods of perchlorate in the environment," Advances in Earth Science, vol. 6, pp. 617-624, 2010.

[19] National Service Center for Environmental Publications, Interim Drinking Water Health Advisory For Perchlorate, p. 12, National Service Center for Environmental Publications, Cincinnati, OH, USA, 2008.

[20] USEPA (United States Environmental Protection Agency), Interim Drinking Water Health Advisory for Perchlorate, US Environmental Protection Agency, Washington, DC, USA, 2008, http://www.epa.gov/safewater/contaminants/ unregulated/perchlorate.html.

[21] B. van Aken and J. L. Schnoor, "Evidence of perchlorate $\left(\mathrm{ClO}_{4}^{-}\right)$reduction in plant tissues (poplar tree) using radiolabeled 36ClO4-," Environmental Science \& Technology, vol. 36, no. 12, pp. 2783-2788, 2002.

[22] K. Kannan, M. L. Praamsma, J. F. Oldi, T. Kunisue, and R. K. Sinha, "Occurrence of perchlorate in drinking water, groundwater, surface water and human saliva from India," Chemosphere, vol. 76, no. 1, pp. 22-26, 2009.

[23] N. Her, H. Jeong, J. Kim, and Y. Yoon, "Occurrence of perchlorate in drinking water and seawater in South Korea," Archives of Environmental Contamination and Toxicology, vol. 61, no. 2, pp. 166-172, 2011.

[24] T. J. Scheytt, J. Freywald, and C. J. Ptacek, "Study of selected soil, ground, and surface water samples on perchlorate in Germany: first results," Grundwasser, vol. 16, no. 1, pp. 37-43, 2011.

[25] Y. Liu, S. Mou, and A. Lin, "Investigation of bromate, haloacetic acids and perchlorate in Beijing's drinking water," Environmental Science, vol. 25, no. 2, pp. 51-55, 2004.

[26] Y. Liu, S. Mou, and S. Heberling, "Determination of trace level bromate and perchlorate in drinking water by ion chromatography with an evaporative preconcentration technique," Journal of Chromatography A, vol. 956, no. 1-2, pp. 85-91, 2002.

[27] Y. Liu and S. Mou, "Determination of trace levels of haloacetic acids and perchlorate in drinking water by ion chromatography with direct injection," Journal of Chromatography A, vol. 997, no. 1-2, pp. 225-235, 2003.

[28] USGS (U.S. Geological Survey), Resources on Isotopes: Periodic Table-Chlorine, 2006, http://wwwrcamnl.wr.usgs. gov/isoig/period/cl_iig.html.

[29] N. C. Sturchio, J. K. Böhlke, B. Gu, P. B. Hatzinger, and W. A. Jackson, "Isotopic tracing of perchlorate in the 
environment," in Handbook of Environmental Isotope Geochemistry, pp. 437-452, Springer, Berlin Heidelberg, 2011.

[30] N. C. Sturchio, P. B. Hatzinger, M. D. Arkins, C. Suh, and L. J. Heraty, "Chlorine isotope fractionation during microbial reduction of perchlorate," Environmental Science \& Technology, vol. 37, no. 17, pp. 3859-3863, 2003.

[31] J. K. Böhlke, N. C. Sturchio, B. Gu et al., "Perchlorate isotope forensics," Analytical Chemistry, vol. 77, no. 23, pp. 7838-7842, 2005.

[32] N. C. Sturchio, J. K. Böhlke, B. Gu et al., "Stable isotopic composition of chlorine and oxygen in synthetic and natural perchlorate," in Perchlorate Environmental Occurrences, Interactions, and Treatment, J. D. Coates, Ed., Springer, New York, NY, USA, 2006.

[33] H. Bao and B. Gu, "Natural perchlorate has a unique oxygen isotope signature," Environmental Science \& Technology, vol. 38, no. 19, pp. 5073-5077, 2004.

[34] W. A. Jackson, J. K. Böhlke, B. Gu, P. B. Hatzinger, and N. C. Sturchio, "Isotopic composition and origin of indigenous natural perchlorate and Co-occurring nitrate in the southwestern United States," Environmental Science \& Technology, vol. 44, no. 13, pp. 4869-4876, 2010.

[35] N. C. Surchio, J. K. BÖhlke, and A. D. Beloso, "Oxygen and chlorine isotopic fractionation during perchlorate biodegradation: laboratory results and implications for forensics and natural attenuation studies," Environmental Science and Technology, vol. 41, pp. 2796-2802, 2007.

[36] P. B. Hatzinger, J. K. Böhlke, N. C. Sturchio, B. Gu, L. J. Heraty, and R. C. Borden, "Fractionation of stable isotopes in perchlorate and nitrate during in situ biodegradation in a sandy aquifer," Environmental Chemistry, vol. 6, no. 1, pp. 44-52, 2009.

[37] J. K. Bölke, S. J. Mroczkowski, N. C. Sturchio et al., "Stable isotope analyses of oxygen (18O:17O:16O) and chlorine (37Cl: $35 \mathrm{Cl}$ ) in perchlorate: reference materials, calibrations, and interferences," Rapid Communications in Mass Spectrometry, vol. 31, pp. 85-110, 2017.

[38] B. Gu, J. K. BÖhlke, and N. C. Sturchio, "Removal, recovery and fingerprinting of perchlorate by ion exchange processes," Ion Exchange and Solvent Extraction: A Series of Advances, CRC, Boca Raton, FL, USA, 2011.

[39] J. Sun, S. Sun, and M. Fan, "Pollution control technologies of perchlorate in water," Chinese Journal of Environmental Engineering, vol. 2, no. 4, pp. 461-465, 2008.

[40] B. Gu, G. M. Brown, L. Maya, M. J. Lance, and B. A. Moyer, "Regeneration of perchlorate $\left(\mathrm{ClO}^{-}\right)$-Loaded anion exchange resins by a novel tetrachloroferrate $\left(\mathrm{FeCl}^{-}\right)$displacement technique," Environmental Science \& Technology, vol. 35, no. 16, pp. 3363-3368, 2001.

[41] Guidance Document, "Validation of chlorine and oxygen isotope ratio analysis to differentiate perchlorate sources and to document perchlorate biodegradation," https://citeseerx. ist.psu.edu/viewdoc/download?doi=10.1.1.362. 8431\&rep $=$ rep $1 \&$ type $=$ pdf.

[42] N. C. Sturchio, M. Caffee, A. D. Beloso Jr et al., "Chlorine-36 as a tracer of perchlorate origin," Environmental Science \& Technology, vol. 43, no. 18, pp. 6934-6938, 2009.

[43] C. J. Eastoe, T. M. Peryt, O. Y. Petrychenko, and D. GeislerCussey, "Stable chlorine isotopes in Phanerozoic evaporites," Applied Geochemistry, vol. 22, no. 3, pp. 575-588, 2007.

[44] K. Purnendu, P. Dasgupta, M. Kalyani, and W. Andrew Jackson, "The origin of naturally occurring perchlorate: the role of atmospheric processes," Environmental Science \& Technology, vol. 39, pp. 1569-1575, 2005.
[45] B. Rao, T. A. Anderson, G. J. Orris et al., "Widespread natural perchlorate in unsaturated zones of the southwest United States," Environmental Science \& Technology, vol. 41, no. 13, pp. 4522-4528, 2007.

[46] E. T. Urbansky, S. K. Brown, M. L. Magnuson, and C. A. Kelty, "Perchlorate levels in samples of sodium nitrate fertilizer derived from Chilean caliche," Environmental Pollution, vol. 112, no. 3, pp. 299-302, 2001.

[47] G. Michalski, J. K. Böhlke, and M. Thiemens, "Long term atmospheric deposition as the source of nitrate and other salts in the Atacama Desert, Chile: New evidence from mass-independent oxygen isotopic compositions," Geochimica et Cosmochimica Acta, vol. 68, no. 20, pp. 4023-4038, 2004.

[48] G. E. Ericksen, "The Chilean nitrate deposits," American Scientist, vol. 71, no. 4, pp. 366-374, 1983.

[49] P. K. DasGupta, J. V. Dyke, A. B. Kirk, and W. A. Jackson, "Perchlorate in the United States. Analysis of relative source contributions to the food chain," Environmental Science \& Technology, vol. 40, no. 21, pp. 6608-6614, 2006.

[50] S. Susarla, T. W. Collette, A. W. Garrison, N. L. Wolfe, and S. C. McCutcheon, "Perchlorate identification in fertilizers," Environmental Science \& Technology, vol. 33, no. 19, pp. 3469-3472, 1999.

[51] N. Estrada, T. A. Anderson, J. K. Bohlke et al., "Origin of the isotopic composition of natural perchlorate: experimental results for the impact of reaction pathway and initial $\mathrm{ClOx}$ reactant," Geochimica et Cosmochimica Acta, vol. 311, 2021.

[52] A. L. Seyfferth, N. C. Sturchio, and D. R. Parker, "Is perchlorate metabolized or Re-translocated within lettuce leaves? A stable-isotope approach," Environmental Science \& Technology, vol. 42, no. 24, pp. 9437-9442, 2008.

[53] N. C. Sturchio, J. K. Böhlke, A. D. Beloso Jr, S. H. Streger, L. J. Heraty, and P. B. Hatzinger, "Oxygen and chlorine isotopic fractionation during perchlorate biodegradation: Laboratory results and implications for forensics and natural attenuation studies," Environmental Science \& Technology, vol. 41, no. 8, pp. 2796-2802, 2007.

[54] M. L. Coleman, M. Ader, S. Chaudhuri, and J. D. Coates, "Microbial isotopic fractionation of perchlorate chlorine," Applied and Environmental Microbiology, vol. 69, no. 8, pp. 4997-5000, 2003.

[55] M. Ader, S. Chaudhuri, and J. D. Coates, "Microbial perchlorate reduction: a precise laboratory determination of the chlorine isotope fractionation and its possible biochemical basis," Earth and Planetary Science Letters, vol. 269, pp. 604-612, 2008.

[56] N. C. Sturchio, A. D. Beloso Jr., and L. J. Heraty, "Isotopic evidence for agricultural perchlorate in groundwater of the western chino basin," in Proceedings of the Sixth International Conference On Remediation Of Chlorinated And Recalcitrant Compounds, pp. 18-22, Monterey, CA, USA, May 2008.

[57] J. K. Böhlke, P. B. Hatzinger, and N. C. Sturchio, "Atacama perchlorate as an agricultural contaminant in groundwater: isotopic and chronologic evidence from Long Island, New York [J]," Environmental Science and Technology, vol. 43, pp. 5619-5625, 2009.

[58] N. C. Sturchio, J. R. Hoaglund III, R. J. Marroquin et al., "Isotopic mapping of groundwater perchlorate plumes," Ground Water, vol. 50, no. 1, pp. 94-102, 2011.

[59] K. Purnendu, V. D. Y. K. E. Dasgupta Jason, and B. Andrea, "Perchlorate in the United States. Analysis of relative source contributions to the food chain," Environmental Science and Technology, vol. 40, pp. 6608-6614, 2006. 